\title{
Role of KVK, Namakkal in Floriculture - Makes Fragrance to Farmers Livelihood
}

\author{
C. Sharmila Bharathi ${ }^{1 *}$, B. Mohan ${ }^{2}$ and N. Akila ${ }^{1}$ \\ ${ }^{1}$ Krishi Vigyan Kendra, Veterinary College and Research Institute Campus, \\ TANUVAS, Namakkal-637 002, Tamil Nadu, India \\ ${ }^{2}$ VC\&RI, TANUVAS, Namakkal, Tamil Nadu,India \\ *Corresponding author
}

\begin{tabular}{|l}
\hline Ke y w or d s \\
KVK, Floriculture, \\
$\begin{array}{l}\text { Farmers } \\
\text { livelihood }\end{array}$ \\
\hline Article Info \\
\hline $\begin{array}{l}\text { Accepted: } \\
\text { 20 January } 2019 \\
\text { Available Online: } \\
\text { 10 February } 2019\end{array}$
\end{tabular}

Keywords

KVK, Floriculture,

Farmers

Article Info

Accepted:

20 January 2019

Available Online:

\section{A B S T R A C T}

Cultivation of flower has now become an important agri-business all over the world. There is high demand for the flower in Namakkal District especially during festival seasons and special occasions. Tapioca is the major tuber crops cultivated in Namakkal District. Due to severe reduction of price in tapioca tuber, long crop duration, monopoly in the marketing system and minimum net profit lead to gradual reduction of area under tapioca cultivation from 15260 ha to 6000 ha. Moreover less arrival of flowers from Namakkal due to minimum area of flower crops cultivation and low production creates more demand for flowers in the Namakkal market. Hence many OFT and FLD programmes relevant to flower crops being implemented by KVK, Namakkal in farmers field from 2008 to till date. The interventions made by KVK, Namakkal on flower crops cultivation have empowered farmers of Namakkal District and also $20 \%$ of the horticultural farmers converted from tapioca farming to flower cultivation because of its short duration, daily income and market preference.

\section{Introduction}

Floriculture has emerged as an alternative source of livelihood for small and marginal farmers. Floriculture was adopted because of the various advantages associated with it, such as limited (or less) seed capital requirement since it was a small-scale cultivation, it generated faster income compared to other farming, and management is easier, not to forget the permanent income opportunity from selling the flowers (Arumugam et al., 2002). The area under flower crops in Namakkal District is 375 ha with a production of 1750.32 MT /year. The major flower crops being cultivated in this 
District are Jasmine, Tuberose, Marigold, Rose, Neerium, Chrysanthemum, Celosia, Ixora and Taberna. Among the 15 blocks in Namakkal District, Erumapatti, Rasipuram, Namagiripettai, Mohanur and Sendamangalam are the major flower producing blocks.

\section{Problems}

Tapioca is the major tuber crops cultivated in Namakkal District in an area of 15260 ha during 2006. Due to severe reduction of price in tapioca tuber@4800-5000/tonne and also long crop duration (10 months), monopoly in the marketing system and minimum net profit (Rs.32000/0.4 ha in 10 months) lead to gradual reduction of area under tapioca cultivation from 15260 ha to 7400 ha in 2010 $-2011 \& 6000$ ha in $2015-16$.

Moreover less arrival of flowers from Namakkal due to minimum area of flower crops cultivation and low production creates more demand for flowers in the Namakkal market. Since 2008, most of the flowers such as Jasmine, Tuberose, Chrysanthemum, Marigold and Rose arrived from neighbouring districts viz., Salem, Dindigul, Trichy and Dharmapuri to Namakkal district for garland making.

Hence $20 \%$ of the horticultural farmers converted from tapioca farming to flower cultivation. Because of its short duration, daily income and market preference.

\section{Flower crop wise interventions}

\section{Tuberose- Polianthes tuberosa}

KVK, Namakkal identified the following problems in flower crops cultivation. Tuberose is one of the most important flower crop in Namakkal district of Tamil Nadu, which is cultivated in an area of 135 ha with a productivity of 4.2 tonnes / ha. Majority of the farmers cultivated Boomudi local variety of tuberose, which is a low yielder.

\section{Problems}

Due to this problem, KVK, Namakkal conducted Front Line Demonstration (FLD) in 20 farmer's field in an area of 2 ha at Valyapatti to assess the performance of high yielding tuberose cv.Prajwal with integrated crop management practices.

\section{Interventions}

The results of the experiment revealed that Tuberose cv.'Prajwal' performed best in certain parameters including days to sprouting of bulb (7.80), bulblet weight at planting $(47.8 \mathrm{~g})$,number of bulblets per clump (20.81),plant height $(107.24 \mathrm{~cm})$ number of leaves per plant (208.13), days to spike emergence (86.2), flowering duration (15.6), spike length $(83.12 \mathrm{~cm})$, rachis length $(28.91$ $\mathrm{cm})$, number of florets per spike (51.2), length of the floret $(6.20 \mathrm{~cm})$, weight of florets per spike $(73.55 \mathrm{~g})$, number of spikes $/ \mathrm{m}^{2}$ (52 nos), yield of florets per plot (size $2 \times 2 \mathrm{~m}-$ $4.45 \mathrm{~kg}$ ), enhanced flower yield of 11.3 tonnes/ha and highest net income of Rs.2,32,000/- with a benefit cost ratio of $2: 1$ when compared to Tuberose variety Boomudi local. This is in confirmity with the findings of Sarita Dimri et al., (2017).

\section{Achievement}

All the farmers practiced tuberose cultivation opined that tuberose cv. Prajwal cultivation is more profitable and flower merchants from local markets make arrangements for the daily procurement. Similar result was also reported by Ganesh et al., (2013).

The price fluctuation is heavy and it ranges from Rs. 40 /- to Rs.100/- per kg depending upon the production and market demand. This 
gives daily income for about nine months a year and in addition to effective utilization of time and resources.

By seeing the success of this technology 76 number of farmers in the same village and adjoining villages of N. Pudhupatti, Vadugapatti, Aniyapuram, Paramathi, Rasipuram, Sendamangalam and Mekkalnayakanpatti were cultivated Tuberose cv.Prajwal in an area of 132 acres.

\section{Jasmine - Jasminum sambac}

\section{Problems}

In Vadavathur and Jambumadai village, small onion is the major vegetable crop cultivated as an annual crop in more than 400 acres and it is the only source of income. In scarce rainfall situations in NICRA village of Vadavathur and Jambumadai, practice of sole cropping is predominant but it is risky and often results in low yields or sometimes even in crop failure due to erratic monsoon rainfall and skewed distribution. To alleviate these problems in such areas of drought villages of Namakkal district crop diversification with perennial crop is a feasible option to minimize risk in crop production, ensure reasonable returns with limited care.

\section{Interventions}

Additional crop of onion with Jasmine is more profitable and is a key drought coping strategy especially for small and marginal farmers. Hence jasmine (20 cent) + small onion $(80$ cent $)$ cultivation model is demonstrated in crop component mode in NICRA village instead of cultivating small onion as a sole crop in an area of 1 acre/ 0.4 ha.

During 2011 and 2012, KVK, Namakkal has supplied 20,000 number of three months old rooted cuttings of jasmine variety Ramanathapuram Gundumalligai to fourteen number of farmers covering in an area of 5 acres as a sustainable livelihood income generating activity to mitigate drought and poverty.

In Vadavathur village, Jasmine plants started flowering at 4 months after planting. But commercial flowering was started two years after planting. From second year onwards, beneficiaries harvested an average of 100 grams of unopened flower buds / plant for a period of seven months.

Each flower cluster consisted of nine buds with $2.8-3 \mathrm{~cm}$ of bud length, $1.1-1.3 \mathrm{~cm}$ of diameter and 50 grams of flower contained 160 flower buds. The peak flowering season was April - June and lean period was October to January. Similar result was also reported by Kailas Andhale (2012) (Table 1).

The farmers involved in jasmine cultivation sold the flowers at flower auction centre located in Namakkal flower market. The flower merchants maintained individual account for each farmer and wherein the quantity of flower sold, price prevailed in the market and commission towards transport and local middle man for carrying flowers from bus stand to auction centre are recorded.

The flower rates in the market varied daily on the basis of demand and supply. The farmers were paid on a monthly basis after deducting the expenditure incurred on marketing. Each member spent $10 \%$ of the sale price towards transport and marketing. The price of one $\mathrm{kg}$ flower bud of Jasminum sambac ranged between Rs.100 - 300/- till July. Thereafter, the price of one $\mathrm{kg}$ of Jasmine flower fetched around Rs.700. It touchedRs.2000/- per kg during October end - January. Similar higher price was also reported by Ambika (2012). 
For the past seven years, the farmers earned more than Rs.40,000/- from selling jasmine flower per year. Not only this money helped to improve the quality of life, education and health of the farm family but also helped them build their asset base by repairing of their house / vehicles.

When comparing water requirement, in jasmine irrigation is given only during summer (February) and peak flowering period (March - August). Though it is a perennial crop, irrigation is required for only 7 months period viz., February to August at $5 \mathrm{~cm}$ depth under flood irrigation.

Totally 21 irrigations in 7 months @ 10 days interval or 3 irrigation per month is needed for economic harvest of jasmine flower buds. Since it is a drought tolerant crop, remaining months (September to January), sufficient water met from rainfall.

840000 litre of water is irrigated to jasmine from 21 number irrigation in an area of 20 cent in 7 months period.

Whereas in small onion, irrigation is given at same depth of $5 \mathrm{~cm}$ under flood irrigation with a crop duration of 3 months. Totally 16 number of irrigation is required @ 5 days interval. So $25,60,000$ litre of water is supplied from 16 irrigations to small onion. For 2 crops in a year, totally 51, 20,000 litre of water is required in an area of 80 cent.

\section{Achievement}

14 number of farmers benefitted under NICRA scheme. By seeing the success of this technology 56 number of farmers in the same village and adjoining villages of Vadugapatti, N.Pudhupatti, Vazhavanthi and Mekkalnayakanpatti upscaled the Jasmine cultivation in an area of 40ha.

\section{Marigold - Tagetes erecta}

\section{Problem}

Marigold is an annual flower crop. In Namakkal District, it is cultivated in Mohanur, Paramathi, Erumapatti, Namagiripettai and Rasipuram blocks in an area of 42 ha with a productivity of 6 tonnes/acre. The major problem faced by farmers in marigold cultivation is occurrence of male flower bud, low yield \& low blooming period.

\section{Interventions}

KVK, Namakkal conducted Front Line Demonstration (FLD) in 10 farmer's field at Puliyampatti, Aniyapuram and Tholur villages in Mohanur block of Namakkal District in an area of 0.4 ha to rectify the above mentioned problems.

Marigold cv. Arka Alankara came to flowering 40 days after transplanting and continues to flowering for next 65 days. Flowers are medium in size with $6.8-7.5 \mathrm{~cm}$ diameter and $6.7-10.4 \mathrm{~cm}$ of stalk length. This is in confirmity with the findings of Mahantesh et al., (2018).

Every day 50 - $70 \mathrm{~kg}$ of flowers harvested from 1000 plants in 20 cent area and sold at the rate of Rs. $20 / \mathrm{Kg}$. When compared to other varieties and private hybrids, it yielded 10 tonnes of flowers per acre in 4 months crop duration.

Single plant produced 48 to 65 flowers in good condition. The farmers got net income of Rs.1, 20,000 with a benefit cost ratio of 2.5: 1.0

\section{Achievement}

The area under marigold cultivation is extended from 42 ha to 64 ha in last 2 years. 


\section{Other interventions}

Under PPP mode KVK, Namakkal supplied planting materials of flower crops and ornamental plants. Mainly Jasmine, Tuberose, Neerium, Taberna and Ixora. Farmers booking planting material for cultivation. Among the planting material of flower crops Jasmine (15595 numbers) and Tuberose (307 $\mathrm{Kg}$ ), Neerium occupied the major sales from 2011 to till date. So far 157 numbers of farmers benefitted and cultivated in an area of 7 acres (Table 2).

In addition to FLD and OFT programmes, regular field visits, diagnostic visit and advisory services were made by KVK, Namakkal to flower growers relevant to variety, cultivation aspects, management of micronutrient deficiency symptoms and IPDM practices.

Table.1 Jasmine flower yield/20 cent from July 2012- May 2017

\begin{tabular}{|c|c|c|c|c|c|}
\hline Year & Month & $\begin{array}{c}\text { Flower } \\
\text { yield (Kgs) }\end{array}$ & $\begin{array}{c}\text { Sales } \\
\text { amount } \\
(\mathbf{R s})\end{array}$ & $\begin{array}{c}\text { Debit amount (Bus } \\
\text { fare @ 10 \% in total } \\
\text { sales amount (Rs.) }\end{array}$ & $\begin{array}{c}\text { Net sales } \\
\text { amount } \\
(\text { Rs.) }\end{array}$ \\
\hline $\mathbf{2 0 1 2}$ & $\begin{array}{c}\text { July 12- Oct 12 } \\
\text { Total }\end{array}$ & 23.9 & 4561 & 456 & 4105 \\
\hline $\mathbf{2 0 1 3}$ & $\begin{array}{c}\text { Jan 13- Nov 13 } \\
\text { Total }\end{array}$ & 296.05 & 46272 & 4627 & 41645 \\
\hline $\mathbf{2 0 1 4}$ & $\begin{array}{c}\text { Jan 14- Nov 14 } \\
\text { Total }\end{array}$ & 420.1 & 64195 & 6419 & 57776 \\
\hline $\mathbf{2 0 1 5}$ & $\begin{array}{c}\text { Jan 15- Nov 15 } \\
\text { Total }\end{array}$ & 545.6 & 81750 & 8175 & 73575 \\
\hline $\mathbf{2 0 1 6}$ & $\begin{array}{c}\text { Jan 16- Nov 16 } \\
\text { Total }\end{array}$ & 505.2 & 101040 & 10104 & 90936 \\
\hline $\mathbf{2 0 1 7}$ & Jan 17- Nov 17 & 520.6 & 104120 & 10412 & 93708 \\
\hline $\mathbf{2 0 1 8}$ & Jan 17- Nov 18 & 618.2 & 123640 & 12364 & 111276 \\
\hline & Grand Total & $\mathbf{2 9 2 9 . 6 5}$ & $\mathbf{5 2 5 5 7 8}$ & $\mathbf{5 2 5 5 7}$ & $\mathbf{4 7 3 0 2 1}$ \\
\hline
\end{tabular}

Table.2 Sale of planting materials of flower crops under PPP mode

\begin{tabular}{|c|c|c|c|c|}
\hline S.No & $\begin{array}{c}\text { Name of the } \\
\text { planting material }\end{array}$ & Variety & $\begin{array}{c}\text { Number } \\
\text { sold }\end{array}$ & $\begin{array}{c}\text { Amount } \\
\text { realized (Rs.) }\end{array}$ \\
\hline $\mathbf{1 .}$ & Rose & Miniature rose, Andhra Red rose & 762 & 38100.00 \\
\hline $\mathbf{2 .}$ & Jasmine & Ramanathapuram & 15595 & 187140.00 \\
\hline $\mathbf{3 .}$ & Hibiscus & Hybrid & 209 & 6970.00 \\
\hline $\mathbf{4 .}$ & Neerium & Red, Pink,White & 2623 & 52460.00 \\
\hline $\mathbf{5 .}$ & Taberna & Single, Double & 519 & 25950.00 \\
\hline $\mathbf{6 .}$ & Ixora & Red, Orange & 402 & 18185.00 \\
\hline $\mathbf{7 .}$ & Tuberose & Prajwal & $307 \mathrm{~kg}$ & 9629.00 \\
\hline $\mathbf{8 .}$ & Shenbagham & Sandal & 395 & 39500.00 \\
\hline $\mathbf{9 .}$ & Parijatham & - & 100 & 5000.00 \\
\hline & Total & $\mathbf{2 0 6 0 5 N o s} / \mathbf{3 0 7} \mathbf{~ K g}$ & & $\mathbf{3 8 2 9 3 4 . 0 0}$ \\
\hline
\end{tabular}


Int.J.Curr.Microbiol.App.Sci (2019) 8(2): 2649-2658
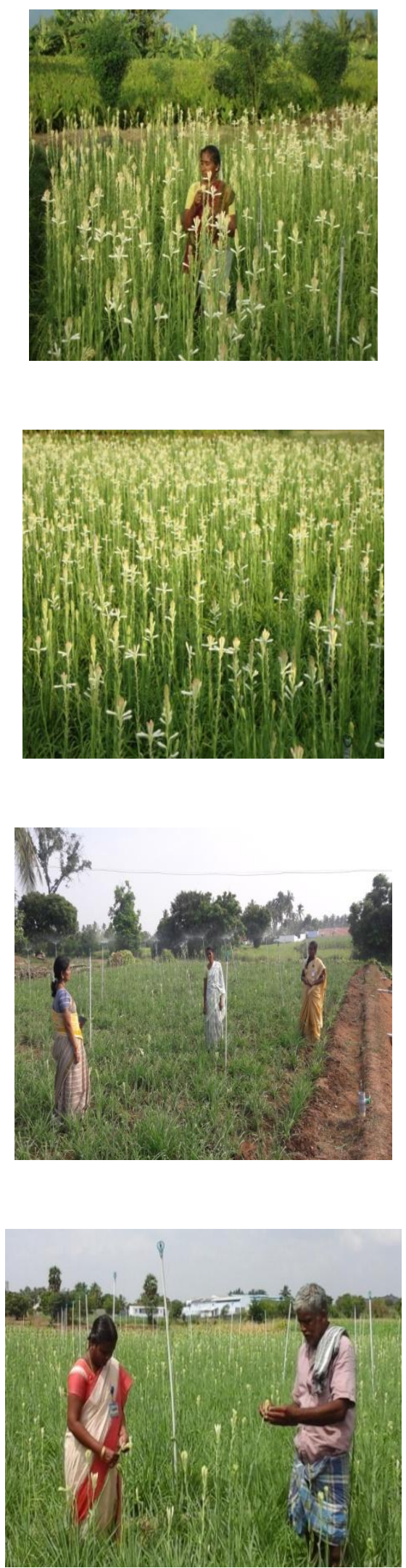
Int.J.Curr.Microbiol.App.Sci (2019) 8(2): 2649-2658
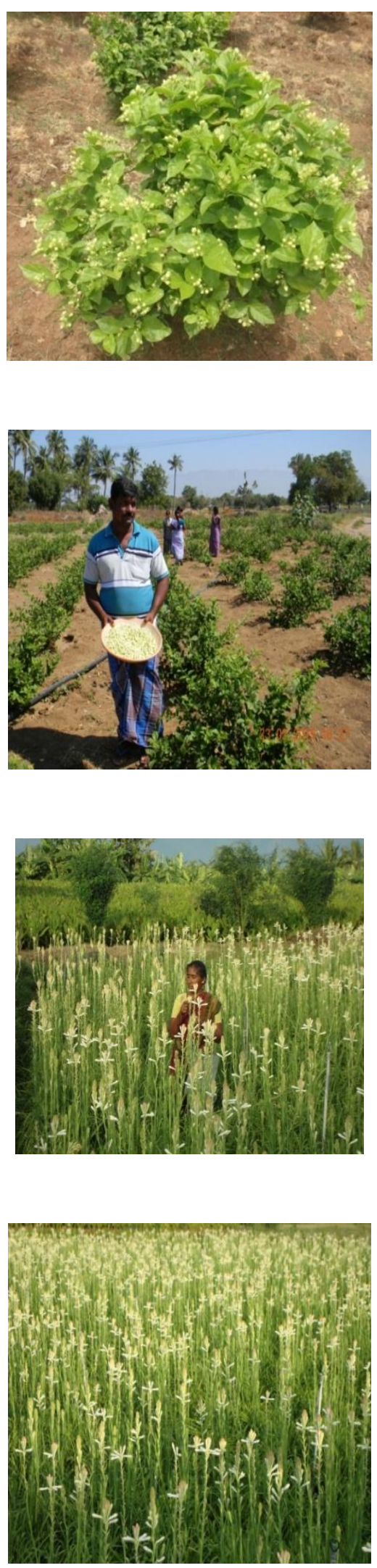
Int.J.Curr.Microbiol.App.Sci (2019) 8(2): 2649-2658
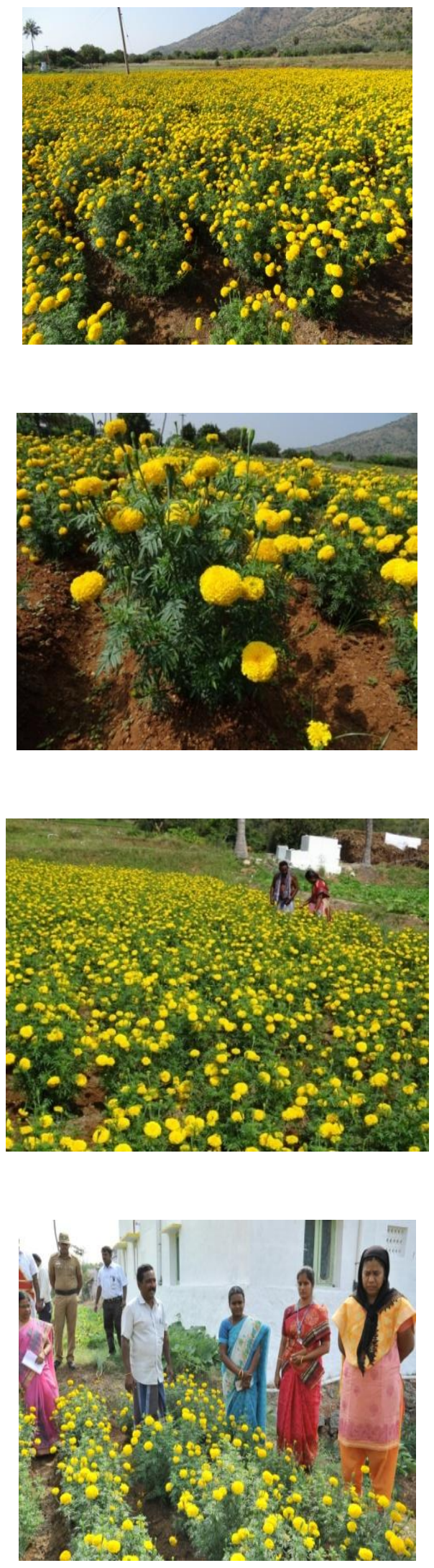

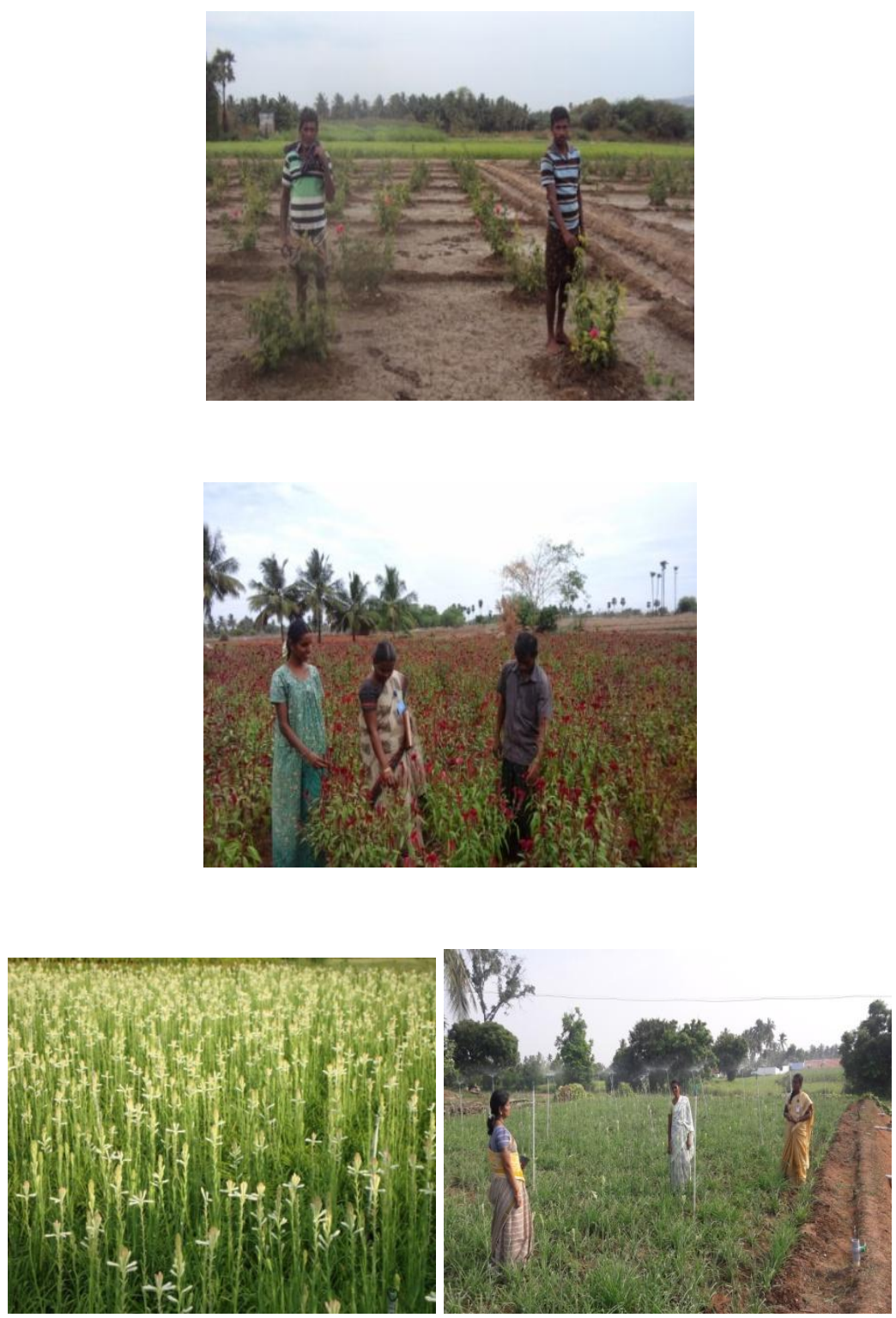

\section{8 -2019 activities}

This year we had taken up FLD on ICM practices in Chrysanthemum var.Col in an area of 1 ha in 8farmers' field in Mohanur blocks. The crop is in flower bud initiation stage.

In conclusion, $20 \%$ of farmers in Namakkal District cultivated Jasmine, Marigold, Tuberose / Neerium as a daily income source in an area of 25 cent to 50 cent throughout the year under the guidance of
KVK, Namakkal through demonstrations, field visits and advisory services since 2008. The farmers directly sell flowers at Namakkal and Karur markets. The Area under flower crops in Namakkal District increased from 112 ha to 375 ha in the last 10 years since floriculture fetch more income to the farmers. Hence the present study revealed that the interventions made by KVK, Namakkalon flower crops cultivation have empowered farmers of Namakkal District, through technological literacy as well as income generation. 


\section{References}

Ambika, T. 2012. Jasmine: Fit for small growers. Market Survey: 19-20.

Arumugham, T., Jawaharlal, M., Vijayakumar, M. and Bhattacharjee, S.K. 2002. Jasmine AICRP on Floriculture Technical Bulletin No. 17. ICAR, New Delhi: 15-19.

Kailas Andhale. 2012. Collective marketing for better income through floriculture. Leisa India, 14 (3): 15 -17.

Ganesh, S., K. Sooriyanathasundaram and M.Kannan.2013.Studies on the effect of plant growth regulators and micronutrients on growth, floral characters and yield of Tuberose (Polianthes tuberosa L.) cv.Prajwal. The Asian Journal of Horticulture:
8(2): 696-700.

Mahantesh KK, P Prashanth, R Chandrashekhar, P Saidaih, Siddappa and Umesh BC .2018. Evaluation of different African marigold (Tagetes species Linn.) genotypes for vegetative, floral and yield attributes under Southern Telangana condition. International Journal of Chemical Studies, 6(5): 3311-3315.

Sarita Dimri, Parul Punetha, Mamta Bohra and Tanuja. 2017. Screening of suitable germplasm of tuberose (Polianthes tuberosa 1.) for mid hill conditions of Garhwal Himalayas. International Journal of Agricultural Science and Research, 7(2): 499-506.

\section{How to cite this article:}

Sharmila Bharathi, C., B. Mohan and Akila, N. 2019. Role of KVK, Namakkal in Floriculture makes Fragrance to Farmers Livelihood. Int.J.Curr.Microbiol.App.Sci. 8(02): 2649-2658. doi: https://doi.org/10.20546/ijcmas.2019.802.310 